\title{
The Process of Learning English Speaking Skills
}

\author{
Ass. Prof. Dr. Shpresë Qamili \\ Vice-Rector for Academic Affairs \\ Public University “KADRI ZEKA”, Gjlan+377 45960781 \\ sq_up@hotmail. com
}

\begin{abstract}
Language gives people the opportunity to express their feelings, desires, thoughts and ideas. Language is a tool, whereby is discovered, acquired, transmitted, stored and inherited knowledge about the world and universe. Language is one of the most significant indicator of linguistics and cultural identity of the language community and individual personality. Language is the carrier of a culture, social behaviour and custom of the respective users. One of the four language skills in the process of learning English, is speaking skill as the first and main form of communication. It occupies a central place in the process of people enlightenment. Information is received, understood and easily processed through speaking or discourse than through writing. The speaking skills are donated to human beings in biological way. Speaking is a vital activity. Meanwhile, the language is a structural model of the system we use to convey our message while we are speaking. This study seeks to assess achievements and to determine the problem areas in the process of learning English speaking skills by high school students overall Kosova, suggesting appropriate recommendations for overcoming obstacles encountered. Thus, through it, are identified communication strategies that second-language learners use, whenever there are discovered linguistics deficiency, as well as difficulties in the process of learning verbal communication; interlinguistisc and intralinguistics communication strategies are revealed, that students use during oral communication, and their skills in the field of discourse are assessed.
\end{abstract}

Keywords: speaking skills, communicative competence, communication strategies, "parasites expressions".

\section{Introduction}

Lecturing is the first and one of the main forms of communication. It occupies a crucial place in the process of enlightenment of the people's mind. The information is received, understood and more easily processed through active speech than through writing. Lecturing is a process of human behaviour that is granted to them biologically.

The people may possess one, two or more languages. When they own two or more languages, they can fluently express their internal discourse in each of them. However, the people who own only one language cannot express their views, but this can be done only in his first language. If a person wishes to become bilingual, he will have to learn another language, in addition to the first language or mother tongue.

During the learning process of speaking, a second language learner faces difficulties and obstacles due to lingual factors and shocking elements of the language, culture and so on. However, the difficulties and problems are inevitable in the learning process of speaking or writing in a second language.

\section{The Process of Communication}

The term "communication" can be defined as the process by which the discourse has to be followed to the other internal communicators. This process can be called as human communication or oral communication. 
Thus, the communicating activities enable the establishment and maintenance of equilibrium, of cooperation and tolerance between people, by placing them in a common line.

The discourse is the method of expression which ensures human cooperation. It is the means by which various activities are coordinated and linked with each other in order to achieve common and mutual goals.

The complete communication process has to be performed by regulating different hierarchical

communication components. They are as follows:

\section{The intended message.}

\section{Coders.}

\section{Signal.}

\section{Channel.}

5. Decoder.

\section{The received message.}

\section{1. The Communicative competence}

The term "communicative competence"1 is seen by many scholars as the main element that covers all forms of communication as conducting means of the speaking community language (users). The term "all forms of communication"2 can be further explained as linguistic competence, that stretches and completes the process of verbal exposure at all levels of society, by involving "the interaction group" with "the interpersonal interaction ", which involve different areas and dialects. Also, the verbal exposure includes any verbal and nonverbal behaviour that has cultural adaptability.

Concerning the points of views that have been said above, it seems that we could expect two kinds of competencies, namely including: (1) the grammatical competences and (2) the communicative competences.

Thus, the "grammatical competences" can be achieved through exposure to language structure, and the "power of communication" can be achieved through exposure to language structure and social behaviour at once, which revolves around some conventional rules, just as they have been set by the society itself.

There are researchers who say that "language competence" is part of "communicative competence"3. So "communicative competence" relates not simply on the implicit recognition of the structure of language, but also through their exposure of the production performance and the endless sense of community clauses in terms of everyday life, using social experience.

\section{2. The teaching and learning in the lecturing process}

The development of spoken language is not simply the expression of the structure of language. The development of spoken language involves the development of pragmatic use, in addition to pronouncing development, the construction of words, phrases, sentences and discourses at the same time as a common process.

The discourse plays a primary role in learning a second language. Learning a second language is realized when a student fails to understand how a second language works within a discourse. Barnes and Seidlhofer underline that "the learning of

\footnotetext{
${ }^{1}$ Hymes, D., "Functions Of Speech: An Evolutionary Approach" në Anthropology and Education, redacted by E. Gruber, F., University Of Pennsylvania Press, Philadelphia, 1961, pp. 24-25.

2 lbid.

${ }^{3}$ Long, M., Richards, J., Methodology In TESOL, Heinle And Heinle Publishers, Boston, 1987, pp. 168-169. 
speech involves the development of new knowledge of on fine and detailed basis such as to why should we communicate, how to communicate and when to communicate, as well as the habits of complex production and management of interaction, which includes the direction of the next question and answer. " 1

\section{3. The Communication Strategy}

The communication strategy is a systematic effort of students to express or to decipher the meaning of words, phrases and sentences in a foreign language, in situations where the necessary systemized rules are not yet entrenched². Earlier, Tarone and her colleagues have defined this phenomenon as a "manufacturing strategy. " 3

Meanwhile, Ellis has come up with its own definition of "communication strategies are psycholinguistic plans, which mainly vivify as part of communicative competence of language users. So potentially, they are aware and serve as surrogate production plans, which cannot be performed by the student himself. " 4

In the process of speech learning, the students use all kinds of strategies, such as: delay of words, Autocorrection, semantic avoiding etc., in order to hide its linguistic shortcomings, as well as to fulfil the task of communication. Some scholars have made various statements regarding the types of communication strategies, used by students.

\section{4. The learning Strategy}

The learning strategy is the epitome of the effort to develop and embed linguistic and psycholinguistic competences in a foreign language. ${ }^{5}$ The learning strategy used by the students differs from the communication strategy itself. However, O'Melli and Çemoti have defined three types of strategies that are used by the second language learners:

(4) The meta-cognitive strategies, including planning for learning and thinking. (5) The cognitive strategies, including ways to treat conscious learning. (6) The social strategies, including learning through interaction with the others.

\section{5. The Strategy and the process}

In terms of the ways that are being used, both the strategy and the process are considered as the same. The strategy relates to how the student reaches a certain use in a given moment of time. The process relates to systematic series of steps by which the pupil reaches the same use in the course of time. Beilistok distinguishes the strategy from the process itself, based on the criterion that considers them as mandatory or selective. ${ }^{6}$ So, the process is a mandatory mental activity, whereas the strategy is a selected mental activity.

\section{6. The testing of speech}

The research studies in the field of second language learning have paid great attention to the communicative behaviour associated with it. Thus, this research focuses mainly on communication strategies, which are being used by the second language learners (in our case, English). Moreover, in this research, the communication strategy is not seen as the ability of students to communicate effectively. This is simply a tactic that students use language to hide gaps in communication.

\footnotetext{
${ }^{1}$ Burns, A., Seidlhofer, B. "Speaking And Pronunciation", në An Introduction to Applied Linguistics, reducted by Norbert, S., Arnold Publication, London, 2001, faqe 210-211.

2 Tarone, Elaine, U. Frauenfelder, and L. Selinker. "Systematicity/Variability and Stability/Instability" in Interlanguage Systems. Brown, H. Douglas, ed., Papers in Second Language Acquisition. Language Learning Special Issue No. 4, 1976, faqe 23-35.

3 lbid.

${ }^{4}$ Ellis, R. The Study of Second Language Acquisition, Oxford University Press, New York, 1994, p. 182.

5 Tarone, E., Frauenfelder, U., Selinker, L., "Systematicity/Variability And Stability/Instability" In Interlanguage Systems" në Papers In Second Language Acquisition, redaktuar nga Brown, H. Douglas, Language Learning, Special Issue, No. 4, 1976, pp. 23-35.

${ }^{6}$ Bialystock, E., "A Theoritical Model Of Second Language Learning" në Language Learning, No. 28, 1978, pp. 69-84.
} 
Thus, the objectives of this study are to identify and test cases and methods of using such strategies by the high school students in Kosovo.

\section{The Analysis of data}

\section{1. The avoidance}

As far as the avoiding attitude is concerned, we have noticed that seven percent of respondents refused to speak English with the author of this paper. So, we think that the reason for this sort of deviation is that students do not want to share with the others the gaps that have to use a second foreign language (in our case, English). So, to hide its shortcomings language students use avoidance strategy. Furthermore, the linguistic shock and cultural shock are other factors as well, which lead them towards the use of this strategy.

\section{2. Syntactic Avoiding}

The avoiding of the words is the strategy that students get using in order to hide their linguistic shortcomings. Once asked, the students gave one-word answers instead of building a regular sentence or by giving incomplete answers.

Thus,

"Happy" it has been given for the question: "What will you do if you get all tens at school?"

"Serve the poor" it has been given for the question "What will you do for your people if you become a leader?"

"Stay home" it has been given for the question "What will you do if it snows while going to school?"

\section{3. Semantic avoiding}

The students avoid the communication about a certain content for which they do not manage to have the available and accurate rules or forms of learning of a foreign language, by talking about similar concepts, which may imply the desired content.

Thus,

"My father go me in car go to the school" it has been given for the question: "What will you do if it sonws while going to school?"

"I think that is a step forward" it has been given for the question: "How would you feel if you go to university?"

"Proud" it has been given for the question: "What will you do for your people if you become a leader?"

\section{4. Literal translation}

The students apply the practice of literally translation from their mother tongue in the second language. We shall give two samples from the corpus of data collected in this case.

Thus,

"She is body busy" it has been griven instead of: "She is expectant", by translating: "Ajo" with "She", "Është" with "Is", "Shtat" with "Body", "I zënë" with "Busy". 
"He is how I" it has been griven instead of "He is like me", by translating "Ai" with "He", "Është" with "Is", "Si" with "How", "Unë" with "l".

The phenomenon of literally translating process during of the production of second language structure is the result of interference of first language. The students connect the words of the first language (in our case, the Albanian) with the words of a second language (in our case, English), which are deposited in their mental vocabulary, regardless or without understanding the structure of the sentence of the second language (in our case, English).

\section{5. Explicit Parasitism}

In certain cases, students use to hide explicit parasitism in the internal process, which takes place in the depths of their minds. Parasitism can be an expressive sound, words or phrases made by the speakers (users), which do not carry any meaning. Even though, the English speakers (users) of the Republic of Kosovo use parasitism such as "eeeee", "yes", "therefore", "namely", "do you understand me", etc., in order to give themselves more time to find the right word that they have been asking for.

Thus, we have:

"It also estimate the cost of buildings... ëëëëë... which means... the main aspect is the computer graphics."

"It can record many programmes and it can be recorded in many programmes and it listed out a lot of programmes... ëëëë ... do you understand me ... so many programmes ... it means ... therefore... that computer can type out your message."

\section{6. The auto-correction process}

The auto-correction is also another strategy that students use when they understand that their discourse is followed by the errors.

During the construction of sentences, the students realized that they were wrong somewhere in the process of communication, therefore they used this self-correcting strategy.

Thus, we have:

"I will spend more time on making ... doing my duty (auto-correction)."

"She will encourage me ... to get better marks in another subjects ... other (auto-correction) subjects also."

\section{7. The delay of words}

The Procrastination of the words is nothing else, than an extension of the syllables. This gives some more time to the speakers (users) to organize their asking expressions, and to decide what to say next.

Thus, we have:

"Music issss ... is quite different nowadays."
"I will try to help... ëëëëë ... the poorrrr ... people if I becoming a doctor."

"My home is in the trainnn ... near the train station."

"I like to drooo ... do many good thirgs ... good things."

3. 8. The repetition 
The students sometimes attempt toward repetition of a sound, a word or several words, in order to gain sufficient time to think of the next word.

Thus, we have:

"Computers can read out ... read out to the blind people."

"I ... I am very happy."

"Nineteen ... nineteen years old."

"Ëëëëë ... I spend my leisure time in the company of my pet animals... ëëëëë... pet animals."

\section{9. The abandoning of the message}

The abandoning the message is a different kind of strategy, which was used by the students when they started communicating to a particular topic, but then blown briefly, because of difficulties in the use of adequate forms or rules of foreign language, in our case, English. Thus, the students stopped themselves in mid-sentence and did not seek help from the teachers to complete the discourse.

Thus, we have:

"Computer is a device that is ... that is used by man in the changing world. Without computers no researching no ... anything can exist ... do you understand me..."

"Computer is a useful electronic device now ... ëëëëe... without computer, the world is... the world cannot exist. Computer is a devize ... now without computers ... computers play a vital role in man's life ... ëëëëë... which means ...".

\section{10. The Sound reduction}

The sound reduction is a strategy that students use when they feel that the thing they want to say is not correct. Instead of avoiding the pronouncing of the word or asking for help, they pronounce the word, reducing significantly their voice. This enables the students to convince themselves that listeners have not heard what was attended to be said and they also feel the satisfaction of completing the sentence. Below, we give samples of this nature.

Thus,

"I like to be an eagle if I an eagle ... I will (reducing of the sound)... learn pride..." it has been given for the question: "What will you for do if you were an eagle?"

"In my leisure time is ... (ulje zëri)... played football..." it has been given for the question: "What will you do in your leisure time?"

"Nineteen... nineteen year (ulje zëri)... my old" it has been given for the question: "How old are you?

\section{11. Resource expansion strategy}

In order to achieve communication goals, the students try to enhance their linguistic resources in one way or another. In the following section, we give the samples of this nature. 
Thus,

"I select the study ... ëëëëë ... in English grup ... ëëëëë ... help to human beings in the world ... ëëëë... I ... get up from my bedding ... am more interest in mathemetics..." it has been given for the question: "Why did you select this study?".

\section{12. Devising of the new words}

The students invent new words in order to convey the desired concept, or in cases where their mental lexicon to express themselves reveal deficiencies in communication. The following samples are of this nature.

Thus,

"Fence-stick" it has been divised for: "post" ("hu");

"Pine-headed" it has been divised for the expression: "blockhead" ("kokëgdhe").

\section{13. Changing of the language}

The students use terms of their mother tongue (in our case, the Albanian), without worrying to translate in the second language (in our case, English). Below, we give samples of this nature.

Thus,

"Më fal" instead of: "excuse me";

"Ç'të themi" it has been used instead of: "what to say";

"Meqë ra fjala" it has been used instead of: "by the way".

\section{14. Approximation}

The Students sometimes use words or similar structure instead, and appropriate word or any right expression, but, nevertheless, it has common semantic features with the desired unit, which is acceptable for this author. Below, we give samples of this nature.

Thus,

"Teacher's work" it has been used instead of: "teaching";

"Bedding" it has been used instead of : "bed";

"Medical group" it has been used instead of: "medical science".

3. 15. The strategy of lingual transfer

The students use the strategy of lingual transfer when facing differences between first language and the second language. Thus, as a result of the lack of similarities in phonological level, within the performance of the students there are present these following types of strategies:

The phonological interference;

The termination of diphthongs; 
The extension of vowels;

The adding vowel at the end of the word;

The mating of consonants.

\section{15. 1. The phonological interference}

In English, there is no consonant [rr], so that the Albanian students tend towards replacing the sound [r] of English with sound $[\mathbf{r}]$ of Albanian, as it is seen in the following cases.

Thus, we have:

[rrok] instead of [rok] "rock";

[rraund] instead of [raund] "round";

[rrab] instead of [rab] "rub".

\section{15. 2. The extinction of diphthong}

Even the phonetic differences of a single phoneme cause interferences. Because of these interferences, often the Albanian speakers when they pronounce English words, they give them an audio dimension of their mother tongue. So, it happens that diphthongized sound become a single voice, as it has been seen in the following cases.

Thus, we have:

[no] instead of [nou] "no";

[so] instead of [sou] "sow";

[ro] instead of [rou] "row";

[roz] instead of [rouz] "rose".

3. 15. 3. The extension of the vowel

Another strategy that has been used by the Albanian speakers is their tendency to prolong terminal vowels diphthongs. From the data collected, it was found that the English words, which are written with the letters "0o", "ou" and "o", as appropriate, elongated vowels are pronounced, as seen in the following cases.

[pu:ër] instead of [puër] "poor";

[tu:ër] instead of [tuër] "tour";

[o:upën] instead of [oupën] "open".

3. 15. 4. Avoiding of consonantal colloquialism

Avoiding or weakening of consonantal colloquy is another strategy used by the students, who tend towards the inclusion of a vowel between clusters consonants, such as "gl", "cr", "pl", "pr", "Im "etc., as seen in the following examples. 
Thus, we have:

[kiriket] instead of [krikit] "cricket";

[pilezhër] instead of [plezhër] "pleasure";

[piraivit] instead of [praivit] "private";

3. 15. 5. Adding a vowel at the end of the word

Another interesting strategy is the addition of the vowel [i] at the end of some words, as seen in the following examples.

Thus, we have:

[e:të] instead of [e:t] "at";

[e:ndë] instead of [e:nd] "and";

[mastë] instead of [mast] "must";

And this phenomenon is due to the influence of the mother tongue (in our case, the Albanian language).

\section{Summary}

\section{1. General Findings}

The discourse plays a primary role in maintaining and developing relations among people. The communication in English takes a core place in all fields of human activity called as "the global village", that is, the world in which we live. Because of this phenomenon, the teaching and learning of English is an inevitable activity in almost all non-English speaking societies. The Republic of Kosovo has a long tradition in terms of teaching and learning English as a second language for the reasons already known. However, to enhance the quality of teaching and learning of English, they are provided and continue to provide guidance and useful recommendations by the drawn conclusions from research studies carried out in this field. The findings of these research studies serve to identify the appropriate solutions for problems related to the teaching and learning of English.

The findings of this study, such as the strategies used by the students when they encounter difficult problems, set out succinctly, while the recommended means for eliminating or at least minimizing them during their learning process of oral communication.

We have understood that, during the process of learning the speech, the students use certain strategies in the communication process, in order to hide linguistic shortcomings. Avoidance is the first and foremost strategy, which is often used by them. Thus, seven percent of students shunned conversation in English with this author to talk about a certain topic because of anxiety, shock language, culture shock and language deficiencies. The avoidance of syntax is a strategy through which the students avoid constructing sentences. Rather than building complete sentences, they try to give elliptical answers to questions that are addressed. The strategy of semantic avoidance is a particular type of strategy, which is used by students to avoid semantic cooperation to the questions asked.

Students apply the practice of literal translating of based on their mother tongue (in our case, from Albanian), in the second language (in our case, in English), and use explicit parasitism in the communication process when faced with the gaps and language shortcomings. They also use the auto-correction strategies, by lengthening and repeating of the words. Through auto-correction strategy, the students come to correct themselves, by using different expressions and grammatical units. The auto-corrected units are sometimes wrong. Meanwhile, the delay of the words has to do with the extension of the syllables. It gives the speaker (the user) a sufficient time in order to ask for the following essential elements. Even the 
repeating is seen as a strategy that is used by the students. When using this strategy, the students repeat certain units, such as words, expressions, partial sentences or even the complete ones. Thus, we have found that repetition of complete sentences gives to the students more time available than the repetition of words or partial sentences.

The students also use the drop-message strategy. The students begin to communicate regarding a specific topic, but in the middle of the lecture, they short-cut it, by leaving it unfinished, due to the difficulty or anxiety-caused by the learning of the elements of linguistic system of a foreign language (in our case, the English).

The students purposely lower their voices when they feel they are making mistakes. The Sonic Reduction Strategy shows that they have no confidence in learning a second language (in our case, in English). The expansion of resources is a particular strategy through which the students try to increase their linguistic resources in place in order to give precise answers to the given questions.

Also, we have discovered that some students invent some new words during the oral communication process in the case when they cannot find the right words, or when the latter are lacking in their mental lexicon. In certain contexts, students use the strategy of changing the code, that is, they use certain words of the first language (in our case, the Albanian) in the second language (in our case, English). The approximation is a strategy through which the students use the related units instead of needed units, therefore, correct. However, these related words have similar semantic features.

Besides the above-mentioned strategies, the students use strategies of intra-lingual and inter-lingual transfer of the elements. Thus, the students use the lingual transfer strategy whenever there are differences between the first language (in our case, the Albanian) and the second language (in our case, English). The linguistic transfer strategies are: (1) phonological interference; (2) Cessation of diphthongs; (3) the duration of the vowel; (4) the avoidance of consonantal cluster; (5) adding the vowel at the end of the word; and (6) coupling the consonants. Finally, we have discovered that the students use intra-lingual transfer strategy in oral communication process whenever there are irregularities in the grammatical rules of a foreign language (in our case, English). This happens in the case of names and verbs, their forms, respectively plural and past tense, the irregular forms. Thus, with respect to the names and irregular verbs, the students apply the rules that include the names and regular verbs.

\section{Recommendations}

In order to reinforce language and communication competence of students in English, the following solutions will be useful and will help to eliminate, or at least to minimize the problems faced by students in the learning process of oral communication.

To develop the linguistic competence of the students the foreign language should be taught linguistically, namely, the lingual access to the teaching of English in the first place might be useful for the development of relevant competencies.

There can be taught different types of oral discourses of the second language (in our case, English), while students may be given sufficient time in order to develop conversational discourse classes. The training in conversational discourse will lead to the elimination of linguistic shock and cultural shock as well. Moreover, it would help to develop the students' communicative competence.

During the teaching of English vocabulary it must be recommended to initially learn grammatical functions of words, focusing mostly on semantic values and their special grammatical behavior.

Similarities and differences between the first language (in our case, the Albanian) and second language (in our case, English) can be used especially during the course of syntax, which would lead to the elimination of the habit of translation word literally from the first language into the second language.

During the lesson enunciation, the phonetic similarities and differences of phonemes can be demonstrated in class, while it is advisable to exercise the right expressions granted in this field. Moreover, the students being familiar with the first language interference (in our case, the Albanian) it's of great importance the pronunciation of sounds in the second language (in our case, English) which should be done at the right time. 
The students can be motivated to interact with their teachers and teaching groups during the process of learning of a second language (in our case, English) at home and in school. Furthermore, the pursuit of programs on radio and television, and reading the daily newspapers in English, will help the development of speaking in this language.

\section{Literature}

Burns, A., Seidlhofer, B. "Speaking And Pronunciation", në An

Introduction to Applied Linguistics, redaktuar nga Norbert, S., Arnold Publication, London, 2001, faqe 210-211.

Bialystock, E., "A Theoritical Model Of Second Language Learning" në Language Learning, No. 28, 1978, faqe 69-84.

Cook, V. Second Language Learning and Language Teaching, Arnold Publication, London, 2001.

De Laguna, G., Speech: Its Function And Development, Yale University Press, New Haven, 1927, faqe 18-20.

Ellis, R. The Study of Second Language Acquisition, Oxford University Press, New York, 1994, faqe 182.

O'Malley, J. M., Chamot, A. U., Learning Strategies In Second Language Acquisition, Cambridge University Press, Cambridge, England, 1990.

Hymes, D., "Functions Of Speech: An Evolutionary Approach" në Anthropology and Education, redaktuar nga E. Gruber, F., University Of Pennsylvania Press, Philadelphia, 1961, faqe 24-25.

Long, M., Richards, J., Methodology In TESOL, Heinle And Heinle Publishers, Boston, 1987, faqe 168-169.

Tarone, Elaine, U. Frauenfelder, and L. Selinker. "Systematicity/Variability and Stability/Instability" in Interlanguage Systems. Brown, H. Douglas, ed., Papers in Second Language Acquisition. Language Learning Special Issue No. 4, 1976, faqe 23-35..

Tarone, E., Frauenfelder, U., Selinker, L., "Systematicity/Variability And Stability/Instability" In Interlanguage Systems" në Papers In Second Language Acquisition, redaktuar nga Brown, H. Douglas, Language Learning, Special Issue, No. 4, 1976, faqe 23-35.

Pinker, S., The Language Instinct: How The Mind Creates Language, William Morrow, New York, 1994, faqe 32-33. 